\section{Avoidance by early flushing: a new perspective on Dutch elm disease research}

\author{
Ghelardini L ${ }^{(1-2)}$, Santini A ${ }^{(2)}$
}

European elms (Ulmus glabra Huds., Ulmus laevis Pall. and Ulmus minor Mill.) have been severely damaged and are still endangered by an alien hypervirulent pathogen, Ophiostoma ulmi s. I., agent of the Dutch elm disease (DED). Consequently, several ex situ clone collections have been established throughout Europe for elm breeding and conservation. In this paper we summarise the studies carried out within the EU project RESGEN CT96-78, which launched the EU-coordinated evaluation of these collections. Our aim was to analyse the variation in timing of bud burst and to acquire basic knowledge on the environmental control of this adaptive trait in European elms, under the hypothesis that DED susceptibility is related to spring phenology. The variation in the bud burst date of European elms among collections and years was explained by a phenological model assuming that the thermal time required for bud burst decreases exponentially with increasing chilling during winter down to a level where chilling requirement is fully met. According to the fitted curves, European elms have low dormancy and short chilling requirement for dormancy release. Although no simulation was performed, on the basis of the model applied we can hypothesise that under climate warming elms would flush earlier in most of Europe. The bud burst date was directly related to latitude and elevation in $U$. minor. The order of bud burst of clones from different origins was stable among years. The observed geographic trends were largely determined by differences in chilling requirements that increased with latitude and elevation. Susceptibility to DED varied greatly within $U$. minor and was directly correlated with geographic origin and bud burst date, southern and early flushing clones showing the least symptoms. Our results suggest that early flushing represents a mechanism of disease avoidance owing to asynchrony between host's susceptible period and time of natural infection by DED vectors (Scolytus). This escape mechanism, combined with true resistance and avoidance owing to unattractiveness for the vector's feeding, might be exploited for breeding DED-resistant clones of indigenous species.

Keywords: Bud burst phenology, DED, Disease escape, Elm, Ulmus, Growth-differentiation balance hypothesis

\section{Introduction}

The fate of elms is linked to humans since prehistoric times. They have provided fuel wood, food, fodder, medicine, wood for furniture, shadow for man and cattle, living support for vine. Elms have also been widely used as ornamental trees to embellish ave-

(1) Department of Plant Biology and Forest Genetics, Swedish University of Agricultural Sciences, Box 7080, S-750 07 Uppsala (Sweden); (2) Istituto per la Protezione delle Piante - CNR, Via Madonna del Piano 10, 50019 Sesto Fiorentino (Florence, Italy)

\section{@ Alberto Santini (a.santini@ipp.cnr.it)}

Received: Mar 02, 2009 - Accepted: Jul 16, 2009

Citation: Ghelardini L, Santini A, 2009. Avoidance by early flushing: a new perspective on Dutch elm disease research. iForest 2: 143-153 [online: 2009-07-30] URL: http:// www.sisef.it/iforest/show.php?id=508 nues and gardens across Europe, North America and China. Unfortunately, starting from around 1910 in north-western Europe two destructive pandemics of Dutch Elm Disease (DED) caused by the introduction of the fungal pathogens Ophiostoma ulmi (Buisman) Nannf. and O. novo-ulmi Brasier afflicted the elms in Europe and North America (Brasier 2000, Guries 2001). The gravity and impressiveness of the damages stirred up the interest of public opinion and researchers to explore solutions to the problem (Rohring 1996).

As a first response to the spreading of the disease, it raised up the idea of searching for DED resistance in elm species and populations, with the hope to eventually enhance natural resistance through breeding. The European elm species, Ulmus glabra Huds., Ulmus laevis Pall., and Ulmus minor Mill., resulted generally susceptible, although rare individuals of the last species and its hybrid $U$. $\times$ hollandica Mill. showed acceptable re- sistance to start with breeding program (Heybroek 1993). The main sources of genes for DED resistance have been found in elm species from Central-Eastern Asia, one of the most important centres of genetic diversity of the genus Ulmus (Smalley \& Guries 1993). Unfortunately, Asian elms do not always meet ornamental and production requirements, or do not adapt easily to different environmental conditions. Therefore, the breeding programs set up in Europe and North America to develop DED resistant elms generally involved cross-breeding of Asian with indigenous species with the aim of combining the disease resistance of Asian elms with growth characteristics and higher degree of local adaptation of indigenous species. The above activities led to the release on market of many DED resistant clones of different parentage successfully exploited for ornamental plantations (Mittempergher \& Santini 2004). Nevertheless, the availability of resistant releases of indigenous species would be desirable also to prevent the possible introgression of genes from alien species into the germplasm of native elms, a phenomenon that has been documented for Ulmus rubra Muhl. in North America and $U$. minor in Europe. Both species naturally hybridize with $U$. pumila, an Asian elm introduced for its good to high DED resistance (Cogolludo-Agustín et al. 2000, Collin 2002a, Goodall-Copestake et al. 2005, Zalapa et al. 2007, Zalapa et al. 2009, Santini et al. 2008)

In the last decade, the consciousness that the DED epidemics and the destruction of habitats could pose European elms populations the threat of severe genetic depauperation or in extreme cases extinction (Collin 2002b), has led to extraordinary ex situ conservation measures (Eriksson 2001, Collin et al. 2004). Several national initiatives for collecting germplasm have been undertaken in Europe and a number of ex situ clone collections of European elms have been established. In order to provide these diverse initiatives with a unitary design within a European scope, a common conservation strategy has been defined for European elms within the European Forest Genetic Resources (EUFORGEN) cooperative program (Collin 2002b) and the "Co-ordination for conservation, characterisation, collection and utilization of genetic resources of European elms" EU project (RESGEN CT96-78) was set up in the late '90s. Ex situ collections are effective for dynamic conservation as far as they contain high genetic variability in adaptive traits, which is the necessary requisite for adaptation and evolution, as well as for genetic improvement by breeding. The genetic variability in quantitative traits with a-daptive value, mainly resistance to DED 


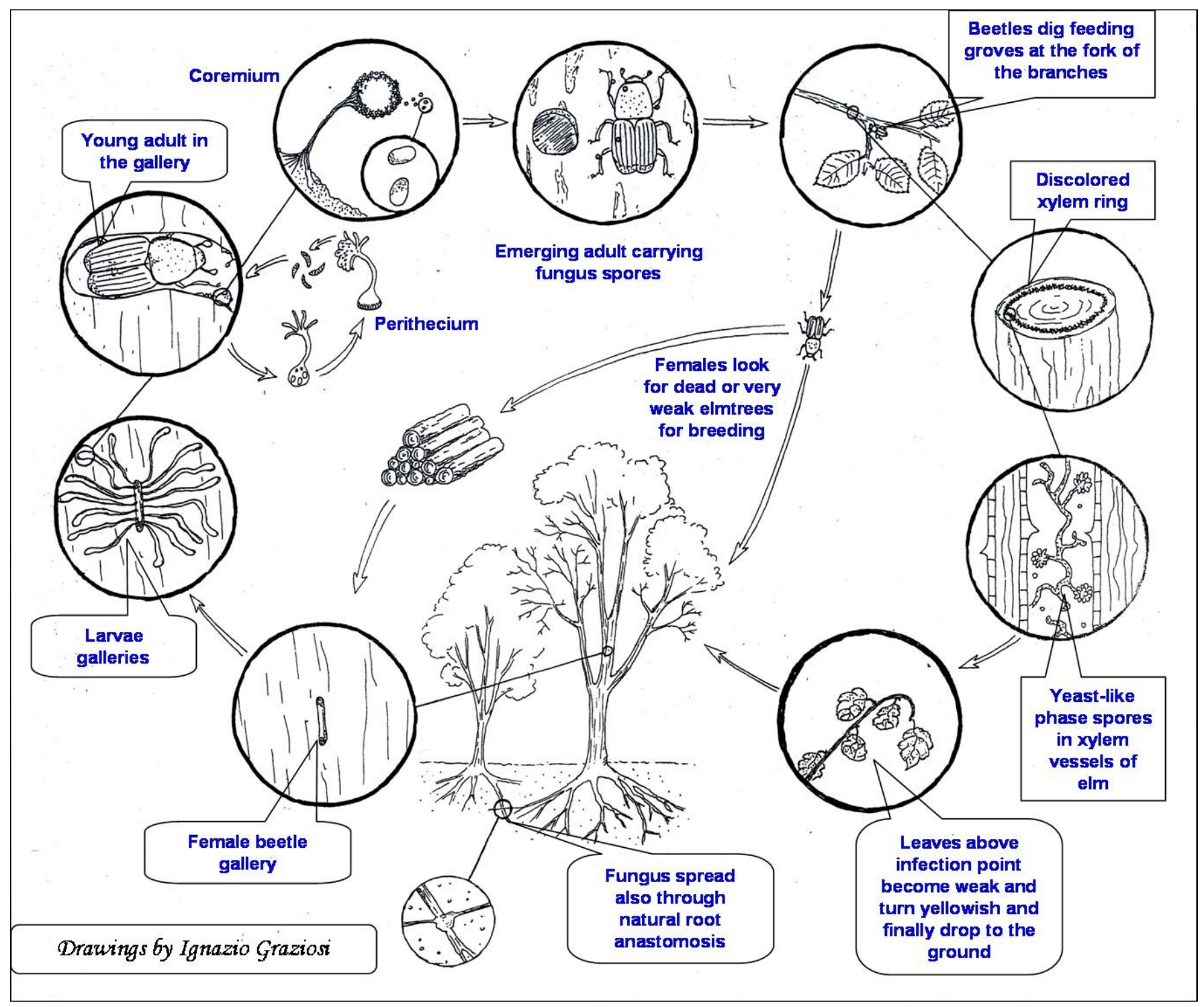

Fig. 1 - Dutch elm disease cycle (courtesy of Ignazio Graziosi).

and phenology, has been investigated within the RESGEN project on the established ex situ collections of European elms. Special attention has been given to bud burst timing that, besides its general ecological importance, potentially affects DED susceptibility.

In this paper we summarise the results of the RESGEN project on bud burst timing and its environmental control with regard to DED susceptibility in elms. We precede the main results of the above investigations with a concise review of the literature on DED more relevant for our work. For a brief literature review on bud burst phenology, bud dormancy and phenology modelling, we refer the reader to Ghelardini (2007).

\section{Disease symptoms and cycle}

DED has a complex infection cycle involving three organisms: the pathogenic fungus, the host tree and the vector insect
(Fig. 1). The disease is transmitted by bark beetles of the genus Scolytus Geoffroy (Coleoptera, Scolitidae - Webber \& Brasier 1984). In Europe, the main vectors are $S$. scolytus and S. multistriatus (Webber 2004). Overwintering young beetles emerge in spring from their hibernating quarters in the bark of dying elms when the threshold temperature necessary for flight (about $20^{\circ} \mathrm{C}$ ) is previously reached for some days (Rudinsky 1962, Webber \& Brasier 1984). They fly to healthy elms for feeding at the crotches of young twigs in the crown. This transient phase is very important for disease transmission as it is the only way for the fungus to reach and infect isolated trees. Contaminated beetles infect elms by carrying pathogen's spores into feeding injuries, in direct contact with the host's vascular tissues. The spores germinate into a growing mycelium and reach the xylem where the pathogen spreads into the vessels through a yeast multiplication phase (Webber \& Brasier 1984). The effectiveness of this process depends on the environmental conditions at the inoculation site, on the amount of inoculum carried by the insect and on the host's susceptibility and physiological state (Sutherland et al. 1997, Webber 2000). Later on, the beetles move to dying elms for breeding into maternal galleries dug in the inner bark of trunks or branches, which provide an ideal environment for both the larvae to develop (Rudinsky 1962) and the fungus to produce fruiting bodies (Webber \& Brasier 1984). The new contaminated beetle generation which emerges from the bark completes the cycle. Depending on the climatic conditions, Scolytus species may produce one or more generations per year (Rudinsky 1962). However, since elms display a seasonal variation in DED susceptibility, reaching the top soon 
after bud burst (Tchernoff 1965, Takai \& Kondo 1979), the generation of beetles most effective for DED transmission is the very first one in spring.

Scolytus vectors of DED are elm-specific (Dixon 1964, Pajares 2004) secondary insects, whose reproduction in healthy and vigorous trees is generally hampered by the strong reaction of the plant. For reproduction they depend on the availability of old or weak elms with cortical tissues thick enough for hosting the breeding activities of the adults and the development of the larvae, but with low reaction to the insect colonization (Rudinsky 1962). The introduction of the DED pathogens therefore provided the elm bark beetles with a massive availability of weakened diseased elms, the ideal plant material suitable for breeding, causing their populations to increase enormously. On the other hand the consequent disappearance of adult elms reduced breeding and caused elm beetles populations to drastically reduce. Thus the vector's populations undergo phases of outbreak and reduction following the dying-out of adult elms and the development of new elm populations (Pajares 2004) The fluctuations of the populations of the three organisms involved follow the LotkaVolterra equations as showed by Brasier (1982).

External initial symptoms of DED include discolouration and wilting of the leaves. The progression of symptoms depends on the infection route. Trees infected in the upper crown by feeding of insects carrying the fungus show rapid wilting, yellowing and drying of the leaves on small branches high in the tree. Symptoms progress on other branches and eventually affect the whole crown. Symptom development is more rapid and severe when DED infection occurs in spring than in summer. If the infection occurs through root anastomosis with infected trees, wilt symptoms are massive and severe throughout the crown and the tree dies rapidly. A typical internal symptom of the disease is the formation of brown streaks in infected sapwood.

During pathogenesis $O$. novo-ulmi develops in the xylem vessels of elms where it produces cell wall degrading enzymes and toxins (Richards 1993, Binz \& Canevascini 1996, Temple \& Horgen 2000). Subsequently the formation of tyloses and gels is observed (Stipes \& Campana 1981, Rioux et al. 1998, Ouellette et al. 2004a, Ouellette et al. 2004b, Et-Touil et al. 2005), a process that results in vessel obstruction and cavitation finally leading to a wilt syndrome (Zimmermann \& McDonough 1978, Newbanks et al. 1983).

\section{Host resistance}

There is considerable variation in host resistance to DED among elm species. The

\section{Box 1 - Glossary}

- Avoidance: A mechanism of disease escape that occurs whenever susceptible plants do not become infected because the factors necessary for disease development (susceptible host, virulent pathogen, and favourable environment) do not coincide and interact at the proper time or for sufficient duration.

- Bud burst: The opening of bud scales followed by elongation of new shoots.

- Chilling: The cold during winter typically referring to temperatures below $10^{\circ} \mathrm{C}$ that act to release buds from dormancy.

- Clone: A plant that is genetically identical to its parents having developed by vegetative reproduction.

- Day degrees: Number of temperature degrees accumulated daily above a threshold temperature, which provides a measure of thermal time.

- Dormancy: A temporary suspension of growth of any plant structure containing a meristem.

- Phenology: The study of the timing of recurrent events in the life cycle of organisms, as influenced by environmental factors, mainly seasonal variation in temperature and precipitation.

- Resistance: The ability of an organism to exclude or overcome, completely or in part, the effect of a pathogen or other damaging factors.

- Susceptibility: The inability of a plant to resist the effect of a pathogen or other damaging factors.

- Thermal time: Growth-promoting heat units accumulated over a period of time.

most resistant are the Asian species U. parvifolia, U. pumila, and U. wallichiana (Smalley \& Kais 1966, Ware 1995, Smalley \& Guries 2000), whereas the Asian U. macrocarpa and $U$. villosa are moderately resistant (Santamour 1979, Ware 1995). The North American elms are generally highly susceptible, while European species are moderately to very susceptible to DED (Gibbs 1978, Dunn 2000). U. glabra is also very susceptible to DED (Solla et al. 2005a), although it may remain unaffected at the northernmost latitudes and highest elevations, where no efficient vector is available (Eriksson 2001, Collin 2002a). U. laevis is susceptible to DED but its populations and individual plants have escaped the disease in many cases, probably because this species is less attractive as a food plant to the Scolytus vectors than the other two European elms (Sacchetti et al. 1990, Webber 2000). Considerable within-species variability in resistance was found in Asian (Smalley \& Guries 1993, Smalley \& Guries 2000) and in European elms, especially U. minor (Smalley \& Kais 1966, Solla et al. 2005a, Pinon et al. 2005, Santini et al. 2005). It should be noticed that resistant elms are not immune to the disease: they become infected but are able to efficiently circumscribe and overcome the infection (Rioux \& Ouellette 1991a, Rioux \& Ouellette 1991b).

Resistance to DED is strictly associated with the host's capacity to quickly localize the infection, preventing the pathogen from both spreading in the vascular system (Sinclair et al. 1975) and reaching the cambium (Shigo \& Tippet 1981, Bonsen et al. 1985). A systemic infection drastically reduces the hydraulic conductivity in the functional xylem, which in elms is limited to the current year ring (Ellmore \& Ewers 1985), mainly because of embolism development and progression (Zimmermann \& McDonough 1978, Newbanks et al. 1983). The process results in a severe wilt syndrome which may cause the tree to die rapidly (MacHardy \& Beckman 1973). Ellmore \& Ewers (1985) reported that large vessels formed in spring at the beginning of the current growing ring are responsible for $96 \%$ of the flow rate in $U$. americana. When the cambium is damaged, the formation of modified tissue for localizing the infection and the production of new vessels replacing the damaged ones are prevented (Bonsen et al. 1985).

A convincing conceptual framework dealing with elm resistance to DED was proposed by Shigo \& Tippet (1981). Their idea is that the localization of the pathogen follows the CODIT model (Compartmentalization Of Decay In Trees - Shigo 1984). Trees capable of quickly compartmentalize the pathogen by means of barrier zone formation will survive the infection, whereas trees with delayed compartmentalization are severely damaged. This model was initially proposed for U. americana (Shigo \& Tippet 1981), but was found to apply also to other elm species (Bonsen et al. 1985) and non-host species (Rioux \& Ouellette 1989, Rioux \& Ouellette 1991a, Rioux \& Ouellette 1991b). The formation of barrier zones may involve a variety of induced defense reactions and is facilitated by pre-existing defense structures (Rioux 1996). Thus, the CODIT model brings together different evidence about factors related to DED resistance. Anatomical characters, such as low vessel diameter and length (Elgersma 1970, Sinclair et al. 1975 , Solla \& Gil 2002) or small size of vessel groups (Pope 1943, McNabb et al. 1970), 
Fig. 2 - Geographic location of the ex situ clone collections of elms comprised in these studies. $1=$ Hann Münden $\left(51^{\circ} 26^{\prime} \mathrm{N}\right.$, $9^{\circ} 38^{\prime}$ E, Germany). 2 = Geraardsbergen $\left(50^{\circ} 46^{\prime} \mathrm{N}, 3^{\circ} 55^{\prime} \mathrm{E}\right.$, Belgium). $3=$ Nogent sur Vernisson $\left(47^{\circ} 51^{\prime} \mathrm{N}, 2^{\circ} 45^{\prime} \mathrm{E}\right.$, France). $4=$ Guémené-Penfao $\left(47^{\circ} 38^{\prime} \mathrm{N}, 1^{\circ} 50^{\prime} \mathrm{W}\right.$, France). $5=$ Antella $\left(43^{\circ} 43^{\prime} \mathrm{N}, 11^{\circ} 22^{\prime} \mathrm{E}\right.$, Italy). $6=$ Puerta de Hierro $\left(40^{\circ} 28^{\prime} \mathrm{N}, 3^{\circ} 45^{\prime} \mathrm{W}\right.$, Spain).

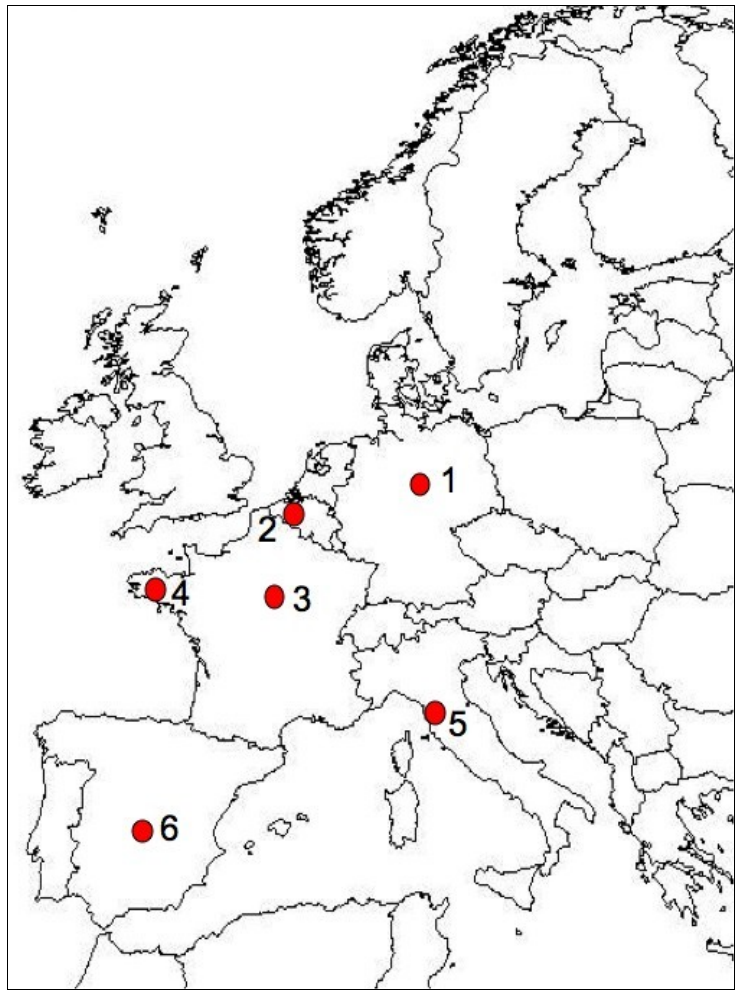

represent a pre-existing (passive) defense strategy. Reactions taking place as a consequence of the infection may be both anatomical and chemical, and they represent a second inducible defense strategy. These reactions include blockage of vessels by tyloses, embolisms, accumulation of pectic and hemicellulosic substances (Elgersma 1982, Shigo 1982, Ouellette \& Rioux 1992, Rioux et al. 1998), formation of chemicals, such as phytoalexin-like sesquiterpenes (Jeng et al. 1983, Duchesne et al. 1985, Sticklen et al. 1991), and histological barriers typically containing phenolic compounds and suberin (Rioux \& Ouellette 1991a, Rioux \& Ouellette 1991b, Ouellette et al. 2004a, Ouellette et al. 2004b, Et-Touil et al. 2005).

Seasonal variation in host resistance in relation to growth rhythm

It has long been known that susceptibility to DED displays strong seasonal variation both in resistant and susceptible species. The time of highest susceptibility, and the duration of susceptibility (i.e., of the period during which elms can become infected and express DED symptoms) varies greatly among elm species and even between provenances and experimental conditions (Banfield 1941, Banfield 1968, Smalley 1963, Smalley \& Kais 1966, Pomerleau 1965, Pomerleau 1968, Tchernoff 1965, Neely 1968, Neely 1970). However, according to the few studies correlating DED susceptibility with host's seasonal development (Pomerleau 1968, Neely 1968, Neely 1970, Takai \& Kondo 1979, Solla et al. 2005b, Santini,
Ghelardini \& Falusi, unpublished data), the time of highest susceptibility coincides with the time of maximum growth rate, the initiation of leaf expansion and the formation of large-size spring vessels. The decrease in susceptibility is correlated to the seasonal changes in wood anatomy from spring to late wood (Pope 1943, Solla et al. 2005b). Hence, the disease development is highly dependent on the host's rhythm of seasonal morphogenesis, including the time of bud burst and reactivation of cambial activity, as well as the pattern of longitudinal and radial growth. Since the compartmentalization efficiency depends on the plant's energetic status, and a slow compartmentalization obliges the plant to keep building new barriers which in turn limit the accessibility of its own reserves in the stem (Bonsen et al. 1985), the CODIT model well addresses also the classic seasonal variation of susceptibility. Susceptibility is highest when the tree's energy reserves are at their minimum, growth rate is highest, photosynthetic apparatus is not fully efficient and vessels are large.

Since plant response undergoes seasonality and elms are inoculated in a transitory and short phase of the cycle of the vector insects (twig-crotch feeding phase), the disease develops only if the insect's disease-transmission phase and the host susceptibility period overlap. Hence, it can be hypothesised that a tree with its maximum susceptibility period anticipated and short relative to the diseasetransmission phase of the vector has potentially low risk of being infected naturally.
Thus, an asynchrony between host phenology and insect cycle allowing the host trees to avoid the disease may represent a kind of resistance (disease escape). This resistance could be exploited in a breeding program, provided that knowledge is acquired on the host's pattern of seasonal growth and the environmental factors (particularly temperature) regulating it. Within such a breeding program, it would be necessary to study how budburst date and growth rhythm vary in different climate conditions but also how environmental factors control the cycle of the Scolytus vectors.

\section{Phenological studies}

The starting hypothesis for the studies reported below was that DED susceptibility is related to the timing of phenological events in spring. We investigated the relation between DED susceptibility and date of bud burst in European and hybrid elm clones. We also studied in several clone collections (Fig. 2) and years how the bud burst timing of European elms is related to environmental factors and geographic origin with the aim of predicting bud burst date of selected clones. We have posed three main questions: 1) is there any variability in susceptibility to DED in the Italian clone collection? If so, is it possible to show any relationship between disease susceptibility and spring phenology? 2) Can the variation in the bud burst date of European elms observed across sites and years in the clone collections be explained by a phenological model based on temperature? 3) Is there any relationship between timing of bud burst and geographic origin in $U$. minor? If so, can the variation among origins be ascribed to differences in the length and deepness of winter dormancy?

The first priority was to assess DED susceptibility and to investigate its relationship with bud burst phenology. For this aim, a field trial was established in 1998 at Antella (Italy - Santini et al. 2005). Rooted cuttings of four elm species (U. minor, U. glabra, $U$. laevis, $U$. pumila) and natural hybrids ( $U$. minor $x U$. glabra and U. minor $x U$. pumila) obtained from Italian and French clone collections (overall 101 clones - Fig. 2) were planted in a randomised block design with two blocks, each block containing four individuals per clone. Two Dutch hybrid clones 'Lobel' and 'Commelin' were added as benchmarks for relatively high and low disease resistance, respectively. Bud burst was recorded weekly between mid March and early May 2001. Inoculations with a wellknown tester isolate of O. novo-ulmi (H328), which proved to be very aggressive in previous tests, were carried out on May 172001 , when elms are generally very susceptibility to DED in the local area. Percentage defoliation was assessed on three dates during the summer and percentage dieback of the 
crown was recorded twice during the following spring. Data were analysed using oneway ANOVA, with taxonomic group or latitudinal origin of $U$. minor clones as fixed effect. Regression analysis between bud burst date and disease symptoms was applied.

The second issue was to assess whether the variation in timing of bud burst in European elms could be described by a phenological model based on temperature (Santini et al. 2004). To this aim, the bud burst phenology of 386 U. minor, $386 \mathrm{U}$. glabra and $103 \mathrm{U}$. laevis clones was assessed weekly from $\mathrm{Fe}$ bruary to May for one to three years (20002002) in six clone collections in Central and Southern Europe. The bud burst date of each elm species per site and year was defined as the modal value of the phenological data distribution expressed in Julian days (number of days since January ${ }^{1 \text { st }}$ ). Daily mean temperature records were used to calculate chilling and thermal time with three threshold temperatures $\left(2^{\circ}, 5^{\circ}\right.$ and $\left.7^{\circ} \mathrm{C}\right)$ and two methods: 1) accumulated day degrees / chill days above / below the daily mean temperature; 2) accumulated hour degrees / chill hours above / below the hourly mean temperature. November $1^{\text {st }}$ and February $1^{\text {st }}$ were chosen as arbitrary starting dates for chilling and thermal time accumulation, respectively. Approximated mean hourly temperatures simulated with a sine-logarithmic model based on minimum and maximum daily temperature records and day-length (Linvill 1990) were used to calculate thermal time and chilling with method \#2. The relationship between bud burst date and thermal time to bud burst in all sites and years was analysed graphically for each species, as-

Fig. 3 - Relationship between symptoms ( $\%$ defoliation) and latitudinal origin (left) or bud burst date (right) in Ulmus minor clones at Antella (Italy) in spring 2001. There was a positive relationship between latitude and susceptibility $(R=0.99, p<0.001)$, southern clones showing fewer defoliation than northerers. Defoliation and bud burst date were significantly related $(\mathrm{R}=0.74, \mathrm{p}<$ 0.001 ), early flushing clones showing fewer defoliation than late flushing ones. $\mathrm{Jd}=\mathrm{Ju}-$ lian days (days from January 1st). Modified from Ghelardini (2007). sessing thermal time by each of the methods described above. The effectiveness of different regression models (based on alternative estimates of thermal time and chilling) to explain the observed variation of bud burst date among sites and years was evaluated for each species. Model accuracy was expressed as percentage of variance accounted for by the relative fitting functions. Finally, in order to describe bud burst date variation as a function of thermal time and chilling, the inverse exponential model (called "alternating model" - Cannell \& Smith 1983, Kramer 1995, Hänninen \& Kramer 2007) was fitted to the data (eqn. 1).

$$
D D=a+b \cdot e^{(r \cdot C D)}
$$

where DD is the accumulated day degrees $>$ $5^{\circ} \mathrm{C}$; $\mathrm{CD}$ is the number of chill days with mean temperature $\leq 5^{\circ} \mathrm{C} ; a, b$ and $r$ are the model parameters. The parameter $r$ measures the rate at which thermal time decreases when the number of chill days increases. At $\mathrm{CD}=0$, the expected value of the temperature sum equals $a+b$, whereas it tends to the asymptotic value $a$ as CD tends to infinity when there is no further effect of increased chilling.

Finally, in order to investigate the relation between bud burst date and geographic origin in $U$. minor, and to ascertain its stability over years and across contrasting environmental conditions, we analysed the data of several phenology trials in France (Nogentsur-Vernisson - 2002) and Italy (Antella 2000, 2001, 2003, 2004), which included clones from wide latitudinal and altitudinal ranges $\left(36^{\circ} 54^{\prime}\right.$ to $57^{\circ} 22^{\prime} \mathrm{N} ; 0$ to $1200 \mathrm{~m}$ a.s.l.) within the species distribution area.

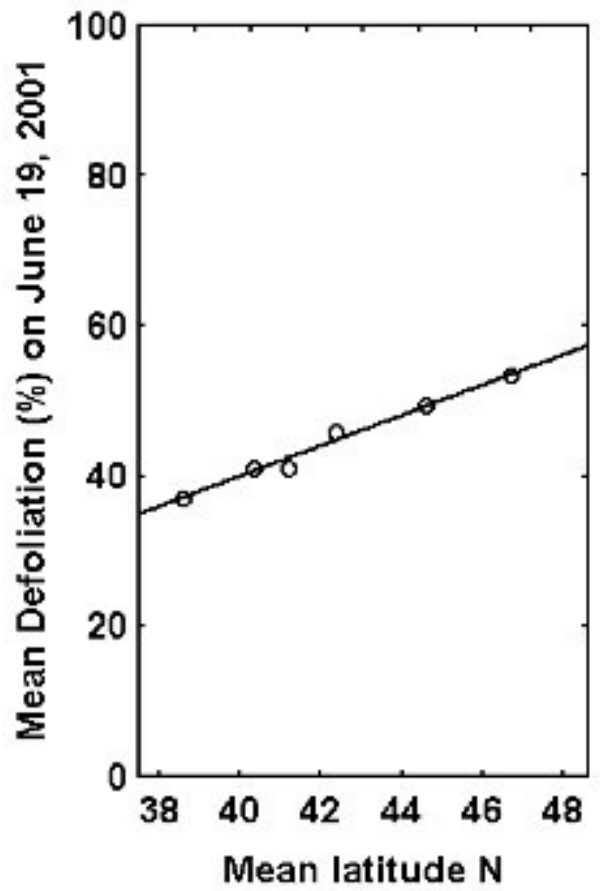

Simple (Nogent-sur-Vernisson) and multiple (Antella) regressions were calculated relating bud burst date and thermal time (day degrees $>5^{\circ} \mathrm{C}$ ) to latitude and altitude of origin. Chill days $\leq 5^{\circ} \mathrm{C}$ were calculated for each year and site combination, and the results of regression analyses were discussed with regard to chilling duration. Moreover, the variation of the bud burst date among sites and years, and the effect of chilling duration on thermal time to bud burst were analysed by means of factorial ANOVAs in four groups of clones from different latitudes (northern France, southern France, northern Italy and southern Italy) at Guèmenè-Penfao and Nogent-sur-Vernisson (years 2000 and 2001) and at Antella (years 2000, 2001, 2004).

Susceptibility to DED is variable in European elms and is related to bud burst phenology

Significant differences in susceptibility to DED were found between elm taxonomic groups (Santini et al. 2005). Natural hybrids between $U$. minor and $U$. pumila were the most resistant and U. glabra the most susceptible species. Highly susceptible clones showed a steady progression of symptoms through the growing season, while relatively resistant clones showed a decrease in symptoms because the flushing of dormant secondary buds partly replaced the damaged crown. In the second year, recurrence of disease symptoms was frequent in clones with extensive defoliation in the previous year, but it also occurred occasionally in other more resistant clones. The highest susceptibility found for U. glabra confirms this spe-

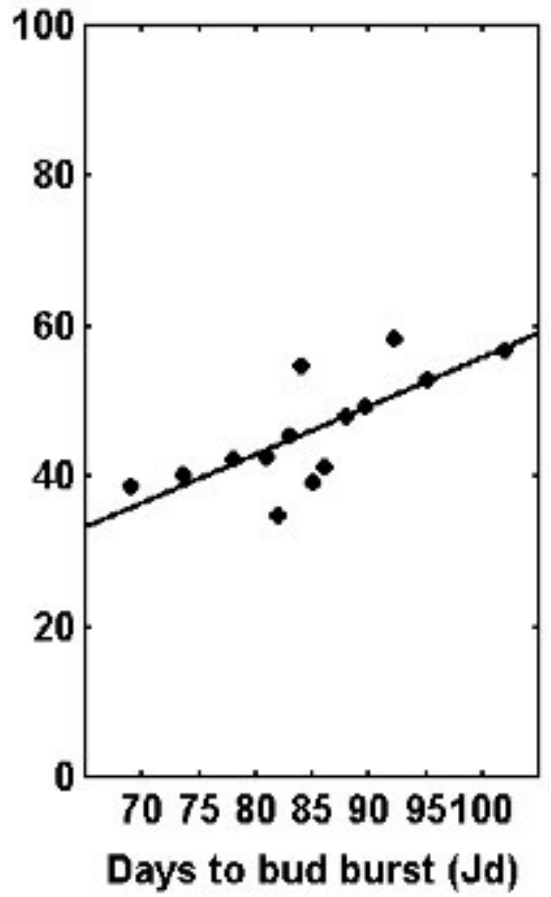


Fig. 4 - Curves obtained by fitting the model in equation 1 (see Materials and Methods) to the bud burst data of Ulmus glabra (circles, dotted line; $\mathrm{DD}=66.9+439.3 \mathrm{e}^{-0.033 \mathrm{CD}}$ ), $U$. laevis (squares, continuous line; $\mathrm{DD}=74.0+434.0 \mathrm{e}^{-0.030 \mathrm{CD}}$ ) and U. minor (triangles, broken line; $\mathrm{DD}=74.6+299.8$ $\mathrm{e}^{-0.025 \mathrm{CD}}$ ) clones. Each point represents the modal value of the bud burst date distribution at a given collection site in a given year. $\mathrm{DD}$ is the accumulated day degrees $>5^{\circ} \mathrm{C}$ since February $1^{\text {st }}$. CD is the number of chill days $\leq 5^{\circ} \mathrm{C}$ since November 1st. Modified from Ghelardini (2007).

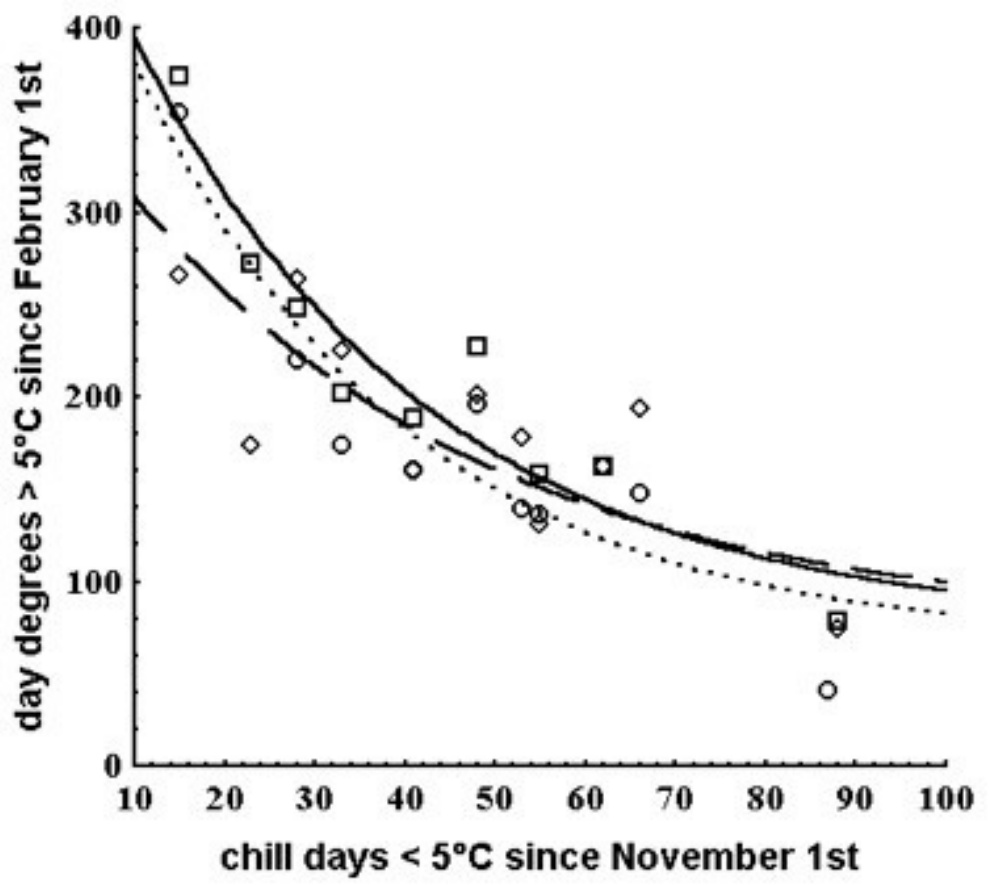

cies as the most susceptible in Europe (Townsend 1971, Brasier 1977, Solla et al. 2005a). U. minor x U. pumila hybrids were the most resistant group. This is a likely effect of the introgression of resistance genes from U. pumila (Smalley \& Guries 2000). Natural hybridisation between U. minor and $U$. pumila in Europe is well documented (Mittempergher \& La Porta 1991, Cogolludo-Agustín et al. 2000, Goodall-Copestake et al. 2005). Natural hybrids with high DED resistance and good capability to adapt to the Mediterranean climate may represent a threat for the genetic integrity of the native species in southern Europe (Santini et al. 2008). At the same time these hybrids could represen a source of resistant plant material for breeding purposes and for genetic research on DED resistance. Within U. minor, the most represented species in the Italian collection, there were significant differences in susceptibility, some clones being even more resistant than 'Lobel'. This was the most promising result since the presence of genotypes with a good level of resistance is the necessary prerequisite for selecting and breeding resistant elms of pure European species.

In addition, a direct relationship was found in $U$. minor between latitudinal origin and susceptibility, southerner clones showing fewer disease symptoms than northerner ones (Fig. 3A), and there was a significant direct relationship between disease severity and bud burst date (Fig. 3B). Ghelardini et al. (2006) reported that southern clones at Antella site flushed significantly earlier in the inoculation year than northern ones. Considering that all clones were inoculated on mid-May (i.e., the time generally favourable for disease development in the Florence area), this result may be explained hypothesizing that southern early-flushing clones stepped over their maximum susceptibility stage by the inoculation date. The period of maximum susceptibility in European elms starts 40-50 days after bud burst and lasts a variable number of days depending on environmental conditions and genotype (Tchernoff 1965, Smalley \& Kais 1966, Santini $\&$ Ghelardini unpublished data). We can assume that southern early-flushing clones had completed the formation of their earlywood vessels and were starting to lay down latewood, a transition linked to the seasonal decrease of susceptibility (Pope 1943, Solla et al. 2005b, Santini, Ghelardini \& Falusi, unpublished data). On the basis of these results, the selection of early-flushing clones may be included in breeding programs to obtain elms avoiding natural infection through an asynchrony between the host's susceptibility period and the Scolytus vector's phase of disease transmission. This approach grounds on the fact that host phenology and the emergence of vectors in spring are regulated by temperature (Sinclair \& Campana 1978, Sengonca \& Leisse 1984).

A phenological model based on temperature explains the variation in timing of bud burst in European elms

Following the results reported in the previous section, our goal was to build appropriate models to predict the bud burst date of interesting clones under various climatic conditions. Among the models applied to phenological data, the most effective ones included the effect of both thermal time and winter chilling as predictors (Santini et al. 2004). In all the species, thermal time to bud burst (day degrees $>5^{\circ} \mathrm{C}$ ) decreased with increasing winter chilling (chill days $\leq 5^{\circ} \mathrm{C}$ ), according to an inverse exponential function. This result suggests that a phenological model including the effect of winter chilling should be considered for predicting bud burst in European elms in a large range of environmental conditions. Goodness-of-fit was not improved by estimating thermal time as hour degrees and chilling as chill hours, which confirms that using hourly weather data as input in bud burst models does not improve their accuracy, as previously reported for other tree species (Cannell \& Smith 1983). Since regressions were slightly improved using $2^{\circ} \mathrm{C}$ as threshold temperature for $U$. glabra and $7^{\circ} \mathrm{C}$ for $U$. minor and $U$. laevis, the use of species-specific thresholds temperatures to quantify temperature effects should be encouraged in future work on bud burst modelling in elms. The "alternating model" (Cannell \& Smith 1983 - eqn. 1) correctly describes the variation in budburst timing in $U$. laevis (total variance accounted for: $89.0 \%$ ) and $U$. glabra $(83.2 \%)$, whereas fitting was relatively poor for $U$. minor $(62.9 \%)$. The fitted curves are shown in Fig. 4. The same model efficiently explained the variation in the bud burst date in Picea sitchensis (Fig. 5A, no. 1; Cannell \& Smith 1983) and in several European trees (Fig. 5A, no. 2, 3 and 4 Murray et al. 1989). Over the chilling range considered here, the regression curves obtained were similar to those typical of lowdormancy tree species as Sorbus aucuparia, Betula pendula, Corylus avellana, Sambucus nigra, Salix viminalis, and Prunus avium (Murray et al. 1989). It can be concluded that European elms have relatively low 

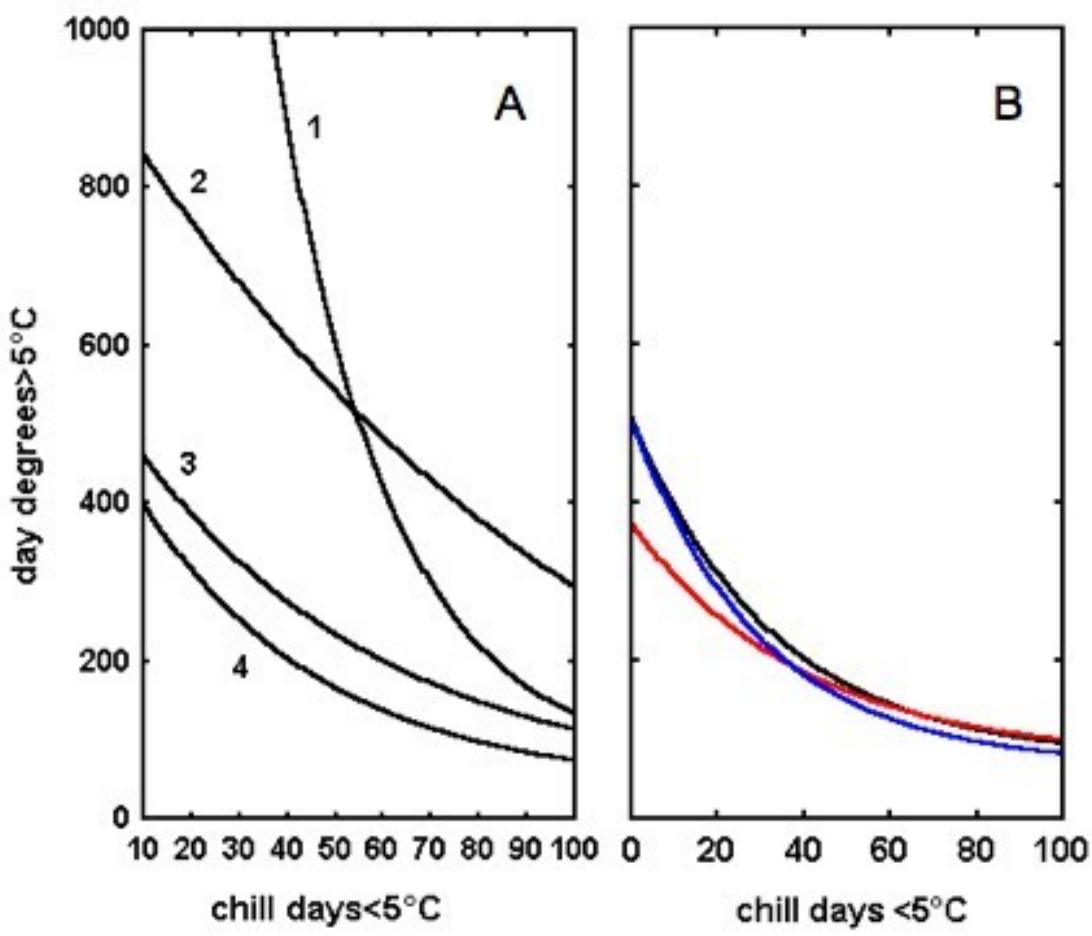

Fig. 5 - Regression curves obtained by fitting the model in equation 1 (see Materials and Methods) to phenological data of some European trees. (A): 1 Picea sitchensis (Cannell \& Smith 1983); 2 Fagus sylvatica (Murray et al. 1989), 3 Sorbus aucuparia, Betula pendula, Corylus avellana (Murray et al. 1989); 4 Sambucus nigra, Salix viminalis, Prunus avium (Murray et al. 1989). (B): Ulmus glabra (blue line), U. minor (red line), U. laevis (black line). Modified from Ghelardini (2007). chilling requirements for dormancy release, their thermal time requirement to bud burst becoming steady when chilling exceeds 100 chill days (Fig. 5B). The "alternating model" has also been successfully used for predicting the bud burst of trees under changing temperature conditions (Murray et al. 1989, Murray et al. 1994). Although no simulations were carried out in the present studies, it can be hypothesised that elms would react to climate warming similarly to other low- dormancy species, flushing earlier over most of Europe (Murray et al. 1989). In central and northern Europe, where the chilling requirement of elms is fully met, no variation in thermal time requirement is expected following the predicted increase in winter temperatures (IPCC 2007). Elms would hence bud burst at an earlier date, as shown for other early flushing trees (Cleland et al. 2007). In southern and western Europe, where the chilling requirement of elms is not fully met, an increase in thermal time requirement is expected following the same temperature upgrade. However, according to our results, the thermal time increment should be limited and would be likely compensated by the rise in spring temperature. We can conclude that even in the warmer part of their distribution range, elms will open their buds earlier following climatic warming. In both cases elms would have to face an increased risk of late frost damage.

\section{Short chilling (Antella 2001)}

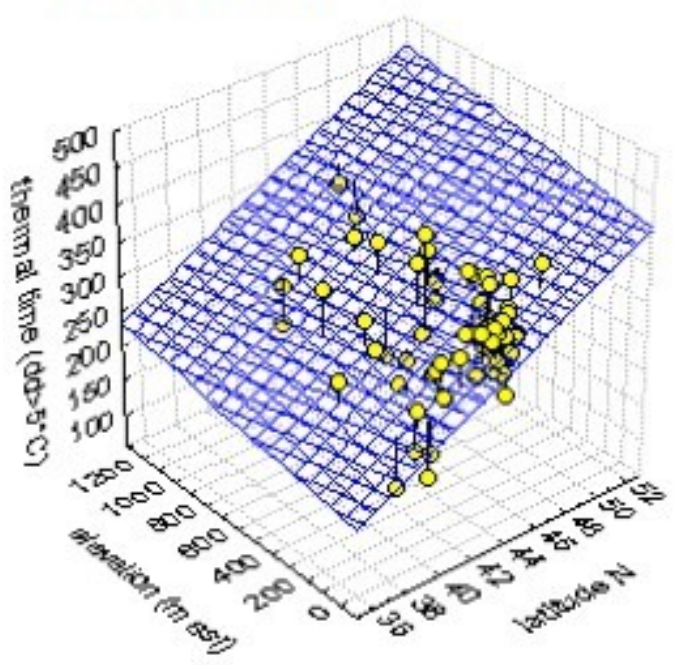

Long chilling (Antella 2004)

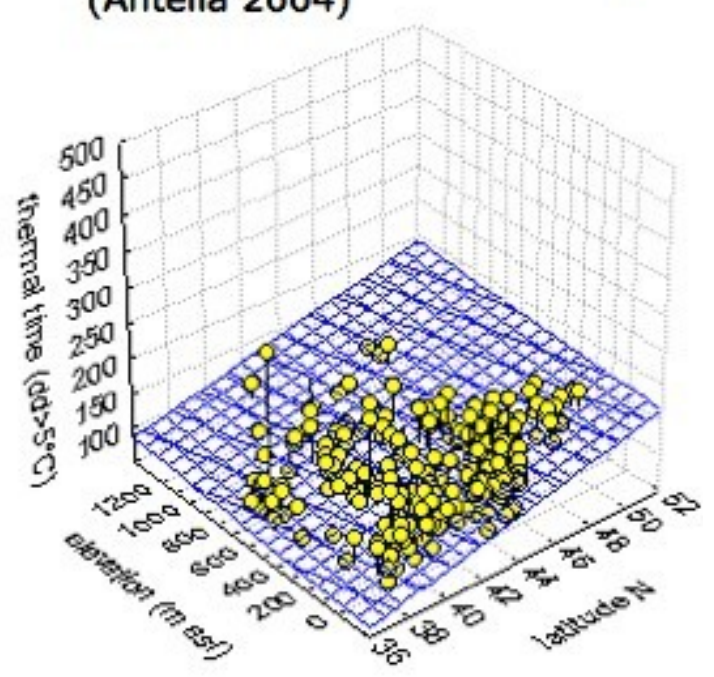

Fig. 6 - Multiple regressions of thermal time (day degrees $>5^{\circ} \mathrm{C}$ ) to bud burst on latitude and altitude for Ulmus minor clones in field conditions at Antella (Italy) in two years with contrasting winter conditions. (A): mild winter in 2001 (chill days $<5^{\circ} \mathrm{C}=15$ ), $\mathrm{R}=0.58, \mathrm{p}<0.01$; (B): cold winter in 2004 (chill days $<5^{\circ} \mathrm{C}=63$ ), $\mathrm{R}=0.50, \mathrm{p}<0.01$. Modified from Ghelardini (2007). 
Timing of bud burst varies largely in Ulmus minor owing to geographic differentiation in chilling requirement for dormancy release

The variability in timing of bud burst within collections was generally large for all species, especially in case of accessions from wide geographic range. Geographic differentiation in dormancy was probably the main source of variance not accounted for in $U$. minor, which explains the poor fitting of the model in this species. Consistently with this hypothesis, goodness-of-fit was greatly improved when the model was applied to phenological data of single provenances or $U$. minor clones (Ghelardini, unpublished data).

The year-to-year variation in the bud burst date within sites was very low for all species despite large differences in winter and spring temperatures (Santini et al. 2004). This result suggests a dual control of dormancy release by temperature and photoperiod in European elms, as it is the case for other trees with a similar stability of the bud burst date (Heide 1993a, Heide 1993b).

A large intra-specific variation in the bud burst date of $U$. minor was observed in the Italian and French collections during several years of study (Ghelardini et al. 2006). Clones from northern latitudes and higher elevations had significantly later bud burst and larger thermal time requirement at both sites in all years. Conflicting results on latitudinal and altitudinal trends of bud burst in trees have been reported from provenance trials, being north to south and high to low elevation trends in bud burst more common but not exclusive (reviewed in Hannerz 1998, Ghelardini 2007). The observed trends in bud burst date and thermal time in $U$. minor at the observation sites, both characterised by mild winters, can be explained as an effect of parallel trends in chilling requirements. It is possible to conclude that in $U$. minor the chilling requirement for dormancy release increases with latitude and altitude, since the difference in thermal time to bud burst among origins diminished in colder winters (Fig. 6), when the requirement of the more chilling-demanding clones from northern latitudes and higher elevations were met to a greater extent, leading to a drastic reduction in their thermal time requirement. This conclusion was further supported by the results of the ANOVA performed on groups of clones from different latitudes in the Italian collection. Differences in thermal time to bud burst among groups were largest in years with very short chilling duration. With increasing the duration of chilling, the thermal time to bud burst decreased earlier in southern clones and became steady after about 50 chill days, whereas in northern clones the thermal time to bud burst continued to decrease over the entire chilling range (Fig. 7A). The chilling re-
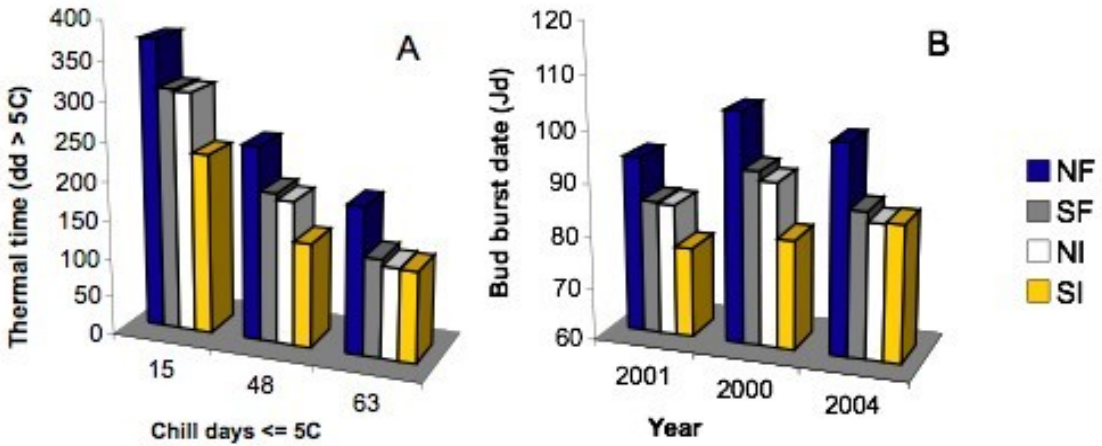

Fig. 7 - Variation in thermal time to bud burst (A) and bud burst date (B) in four groups of Ulmus minor clones from different latitudes $(\mathrm{NF}=$ northern France; $\mathrm{SF}=$ southern France; $\mathrm{NI}=$ northern Italy; SI = southern Italy) at Antella (Italy) among years with different winter temperature conditions (2001, 15 chill days; 2000, 48 chill days; 2004, 63 chill days). $\mathrm{dd}=$ accumulated day degrees $>5^{\circ} \mathrm{C}$. Chill days $=$ days from November 1st with mean daily temperature below $5^{\circ} \mathrm{C}$. $\mathrm{Jd}=$ Julian days (days from January $1^{\text {st }}$ ). Modified from Ghelardini (2007).

quirements were thus fully met only in clones from southern Italy. Reports on the geographical variability in bud burst within European elm species are rare. Whiteley et al. (2003) and Myking \& Skrøppa (2007) observed a north to south latitudinal trend in bud burst among U. laevis and U. glabra provenances, respectively. Since both trials were carried out in Scandinavia, where chilling requirement is likely to be fully met, these bud burst sequences, which are opposite to those observed in the Mediterranean climate, can be attributed to among-populations differences in the thermal time to bud burst or in the base temperature for growth (Worrall \& Mergen 1967, Myking \& Heide 1995).

Clones from different latitudes flushed in the same order over a wide range of temperature conditions (Fig. 7B) and this behaviour was explained by differences in dormancy deepness among origins (Ghelardini et al. 2006). This result is especially noticeable since the stability of bud burst ranking is an essential prerequisite for the exploitation of earliness of flushing to breed DED resistant clones.

\section{Conclusions}

Very few reports on spring phenology and bud dormancy in elms were available so far. The studies reported herein provides new knowledge on this topic. Dormancy in European elms proved to be low according to the species-specific dormancy curves obtained in field conditions (Santini et al. 2004). Although simulations were not performed in these studies, it can be hypothesised that under climate warming European elms would start flushing earlier in most parts of their natural range with increased risk of late frost damage. In $U$. minor a great intra-specific variation in budburst timing was found to be largely dependent on geographic origin. The bud burst date was directly related to latitude and altitude, and the trends were explained by greater chilling requirements for dormancy release in northern / highland than in southern / lowland origins (Ghelardini et al. 2006).

These studies also provided new information on susceptibility to DED. Previous reports by Santini et al. (2005) suggest that early flushing is a mechanism of DED avoidance owing to asynchrony between maximum susceptibility and time of infection. Susceptibility to DED in $U$. minor was related to timing of bud burst, early flushing clones showing less severe disease symptoms than late flushing ones. This relationship was paralleled by a geographic trend in bud burst, southern clones showing fewer disease symptoms than northern ones. Disease avoidance in early flushing clones may be partly determined by an earlier transition from spring to late wood. Besides changes in wood anatomy, other factors such as growth rhythm and leaf expansion are very likely involved in the seasonal variation of susceptibility. These hypotheses are currently tested in elm clones differing in bud burst date and geographic origin (Santini et al., unpublished data).

Variation in susceptibility as related to growth rhythm, either seasonal variation or variation among fast and slow growing plants (Sutherland et al. 1997), fits well in the "Growth-Differentiation Balance Hypothesis" (Herms \& Mattson 1992). This hypothesis provides a framework for predicting possible allocation trade-offs in between differentiation-related and growth-related processes over a range of environmental conditions, since it is known that resources cannot be allocated to both functions simultaneously (Lorio 1986). Similarly to all other plants, 
elms are challenged by the highly unpleasant dilemma: to grow or to defend. Resource availability is large in the Mediterranean region during springtime (when mild temperatures occur along with large water supply) rapidly displaced by an early and dry summer. Elms have indeed to seize the opportunity to grow. Energy reserves of elms in springtime are already exhausted by the flowering process occurring in late winter and by the construction of the new porous ring, which has to provide nutrients for the expanding photosynthetic surface. Growing meristems behave as strong photosynthetic sinks, provisioned by carbon sources that include neighbouring mature leaves (Marcelis 1996) and also newly formed leaves. No resources are dedicated to defence, which makes elms especially susceptible to DED during spring, just in the period of the beetle vector's infective phase. As time passes, resource availability and growth rate decrease so that photosynthates can be allocated to differentiation. This could explain why the infections induced by the second and, potentially, third beetle's generations in summer are less successful or even totally ineffective in causing DED, compared to the first generation's infections in spring.

In early flushing elms the above phenological and physiological events take place earlier in the season, so that trees are already allocating carbohydrates to secondary metabolism when the peak of beetles flight occurs, ensuring therefore a better defence to DED attacks. Moreover, early flushing elms are already producing summerwood that, being constituted by small and scattered vessels and by a greater proportion of fibres, is less suitable to beetles for digging groves and for the diffusion of the spores. This hypothesis is currently tested (Ghelardini et al., unpublished data) in order to verify whether DED avoidance by early flushing could be exploited for selection and breeding of DEDresistant clones of indigenous species. This objective could be achieved through a combination with other types of resistance such as true resistance, which can be introgressed in European elms by recurrent breeding, and avoidance owing to unattractiveness to the vector as a feeding source, which proved to be an efficient mechanism for $U$. laevis to escape DED infection (Sacchetti et al. 1990). Early flushing clones could be selected either from southern populations, provided that they maintain an earlier bud burst compared to local elms, or from local populations, given the large within-population variability expected in wind-pollinated species (Savolainen et al. 2007). Selection for frost resistance should be also included in the breeding program to obtain selected clones with good adaptation to local climate.

After the market release of DED resistant clones, elms are again sought-after as urban and landscape trees because of their fast growth, their adaptability to different soil conditions, their resistance to wind, pruning, root damage, and to city conditions in general. Indeed, foresters call for more clones to be developed in order to achieve material with increased genetic variability and the ability to cope with variable environmental conditions and other diseases. Therefore, the exploration of new approaches to fight DED and to select new resistant clones of indigenous origin is nowadays a matter of considerable interest.

\section{Acknowledgments}

The studies reported herein were partly funded by the EU through the Co-ordination for conservation, characterization, collection and utilization of genetic resources of European Elms RESGEN CT96-78 project. The authors wish to thank Eric Collin for excellent coordination of the project. We warmly acknowledge our co-authors Jürgen Bohnens, Margarita Burón Barrio, Alberto Fagnani, Fabio Ferrini, Alejandro Solla, and An Vanden Broeck. Lorenzo Mittempergher is gratefully acknowledged for sharing with us the precious results of many years of DED research at the Institute for Plant Protection CNR in Florence. We are especially indebted to Mauro Falusi for his indispensable contribution to the analysis and discussion of the phenological data. For his contribute to this work and his support and enthusiasm throughout all these years we want to thank him warm-heartedly. We are grateful to Ignazio Graziosi for kindly drawing the cycle of Dutch elm disease.

\section{References}

Banfield WM (1941). Distribution by the sap stream of spores of three fungi that induce vascular wilt diseases of elm. Journal of Agricultural Research 62: 637-681.

Banfield WM (1968). Dutch elm disease recurrence and recovery in American elm. Phytopathologische Zeitschrift 62: 21-60. - doi: 10.1111/ j.1439-0434.1968.tb02345.x

Binz TG, Canevascini G (1996). Xylanases from the Dutch elm disease pathogens Ophiostoma ulmi and Ophiostoma novo ulmi. Physiological and Molecular Plant Pathology 49: 159-175. doi: 10.1006/pmpp.1996.0046

Bonsen KJM, Scheffer RJ, Elgersma DM (1985). Barrier zone formation as a resistance mechanism of elms to Dutch elm disease. IAWA Bulletin 6 (1): 71-77.

Brasier CM (1977). Inheritance of pathogenicity and cultural characteristics in Ceratocystis ulmi. Hybridisation of protoperithecial and non-aggressive strains. Transactions of the British Mycological Society 68: 45-52.

Brasier CM (1982). The future of Dutch elm disease in Europe. In: "Research on Dutch elm disease in Europe, 1982" (Burdekin DA ed). Forestry Commission Bulletin 60, pp. 96-104.
Brasier CM (2000). Intercontinental spread and continuing evolution of the Dutch elm disease pathogens. In: "The elms: breeding conservation and disease management" (Dunn CP ed). Kluwer Academic Publisher, Boston, USA, pp. 61-72. Cannell MGR, Smith RI (1983). Thermal time, chill days and prediction of bud burst in Picea sitchensis. Journal of Applied Ecology 20: 951963. - doi: 10.2307/2403139

Cleland EE, Chuine I, Menzel A, Mooney HA, Schwarz MD (2007). Shifting plant phenology in response to global change. Trends in Ecology and Evolution 22 (7): 357-365. - doi: 10.1016/ j.tree.2007.04.003

Collin E (2002a). The role of hybridisation in gene conservation. In: "Noble Hardwoods network: Report of the fourth and fifth meetings" (Borelli $\mathrm{S}$ ed). International Plant Genetic Resources Institute, Rome, pp. 50-67.

Collin E (2002b). Strategies and guidelines for the conservation of the genetic resources of Ulmus spp. In: "Noble Hardwoods network: Report of the fourth and fifth meetings" (Borelli S ed). International Plant Genetic Resources Institute, Rome, pp. 50-67.

Collin E, Rusanen M, Ackzell L, Bohnens J, de Aguiar A, Diamandis S, Franke A, Gil L, Harvengt $\mathrm{L}$, Hollingsworth $\mathrm{P}$, Jenkins $\mathrm{G}$, MeierDinkel A, Mittempergher L, Musch B, Nagy L, Paques M, Pinon J, Piou, D, Rotach P, Santini A, Vanden Broeck A, Wolf H (2004). Methods and progress in the conservation of elm genetic resources in Europe. Investigación agraria: Sistemas y Recursos Forestales 13 (1): 261-272.

Cogolludo-Agustín MA, Agúndez D, Gil L (2000). Identification of native and hybrid elms in Spain using isozyme gene markers. Heredity 85: 157-166. - doi: 10.1046/j.1365-2540.2000. 00740.x

Dixon EB (1964). Attack response of the smaller European elm bark beetle, Scolytus multistriatus, in confinement. Journal of Economic Entomology 57 (1): 170-172.

Duchesne LC, Jengand RS, Hubbes M (1985). Accumulation of phytoalexins in Ulmus americana in response to infection by a nonaggressive strain of Ophiostoma ulmi. Canadian Journal of Botany 63: 678-680. - doi: 10.1139/b85-086

Dunn CP (2000). The elms: breeding, conservation and disease management. Kluwer Academic Publishers, Boston, USA.

Elgersma DM (1970). Length and diameter of xylem vessels as factors in resistance of elms to Ceratocystis ulmi. The Netherlands Journal of Plant Pathology 76: 179-182. - doi: 10.1007/ BF01974328

Elgersma DM (1982). Susceptibility and possible mechanisms of resistance to Dutch elm disease. In: Proceedings of the "Dutch elm disease symposium and workshop" (Kondo ES, Hiratsuka Y, Denyer WBG eds). Winnipeg (Manitoba Canada), 5-9 October 1981, pp. 169-177.

Ellmore GS, Ewers FW (1985). Hydraulic conductivity in trunk xylem of elm, Ulmus americana. IAWA Bulletin 6: 303-307.

Eriksson G (2001). Conservation of noble hard- 
woods in Europe. Canadian Journal of Forest Research 31: 577-587. - doi: 10.1139/cjfr-31-4-577

Et-Touil A, Rioux D, Mathieu FM, Bernier L (2005). External symptoms and histopathological changes following inoculation of elms putatively resistant to Dutch elm disease with genetically close strains of Ophiostoma. Canadian Journal of Botany 83: 656-667. - doi: 10.1139/b05-037

Ghelardini L, Falusi M, Santini A (2006). Variation in timing of bud-burst of Ulmus minor clones from different geographical origins. Canadian Journal of Forest Research 36: 1982-1991. doi: 10.1139/X06-092

Ghelardini L (2007). Bud burst phenology, dormancy release and susceptibility to Dutch elm disease in elms (Ulmus spp.). Doctoral thesis no. 2007:134, Acta Universitatis Agriculturae Sueciae, Uppsala, Sweden, pp. 52.

Gibbs JN (1978). Intercontinental epidemiology of Dutch elm disease. Annual Review of Phytopathology 16: 287-307. - doi: 10.1146/annurev.py. 16.090178 .001443

Goodall-Copestake WP, Hollingsworth ML, HollingsworthPM, Jenkins GI, Collin E (2005). Molecular markers and ex situ conservation of the European elms (Ulmus spp.). Biological Conservation 122: 537-546. - doi: 10.1016/ j.biocon.2004.09.011

Guries RP (2001). Elms: past, present, and future In: Proceeding of the "National conference on wilt diseases of shade trees" (Ash CL ed), St. Paul, Minnesota (USA), 25-28 August 1999. APS Press, pp. 29-36.

Hannerz M (1998). Genetic and seasonal variation in hardiness and growth rhythm in boreal and temperate conifers - a review and annotated bibliography. SkogForsk, Report No. 2, pp. 144.

Hänninen H, Kramer K (2007). A framework for modelling the annual cycle of trees in boreal and temperate regions. Silva Fennica 41 (1): 167205.

Heide OM (1993a). Daylength and thermal time responses of budburst during dormancy release in some northern deciduous trees. Physiologia Plantarum 88: 531-540. - doi: 10.1111/j.13993054.1993.tb01368.x

Heide OM (1993b). Dormancy release in beech buds (Fagus sylvatica) requires both chilling and long days. Physiologia Plantarum 89: 187-191. doi: 10.1111/j.1399-3054.1993.tb01804.x

Herms DA, Mattson WJ (1992). The dilemma of plants - to grow or defend. Quarterly Review of Biology 67 (4): 478. - doi: 10.1086/417795

Heybroek HM (1993). The Dutch elm breeding program. In: "Dutch elm disease research: cellular and molecular approaches" (Sticklen MB, Sherald JL eds). Springer-Verlag, New York, USA, pp. 16-25.

IPCC (2007). Climate change 2007: synthesis report. Core Writing Team (Pachauri RK, Reisinger A eds). IPCC, Geneva, Switzerland, pp. 104.

Jeng RS, Alfenas AC, Hubbes M, Dumas MT (1983). Presence and accumulation of fungitoxic substances against Ceratocystis ulmi in Ulmus americana: possible relation to induced resistance. European Journal of Forest Pathology 13:
239-244. - doi: 10.1111/j.1439-0329.1983. tb00124.x

Kramer K (1995). Phenotypic plasticity of the phenology of seven European tree species in relation to climatic warming. Plant Cell and Environment 18: 93-104. - doi: 10.1111/j.1365-3040. 1995.tb00356.x

Linvill DE (1990). Calculating chilling hours and chill units from daily maximum and minimum temperature observations. HortScience 25 (1): 14-16.

Lorio PL (1986). Growth-differentiation balance: a basis for understanding southern pine beetletree interactions. Forest Ecology and Management 14: 259-273.

MacHardy WE, Beckman CH (1973). Water relations in American Elm infected with Ceratocystis ulmi. Phytopathology 63 (1): 98-103.

Marcelis LFM (1996). Sink strength as a determinant of dry matter partitioning in the whole plant. Journal of Experimental Botany 47: 12811291.

McNabb HS, Heybroek HM, MacDonald, WL (1970). Anatomical factors in resistance to Dutch elm disease. The Netherlands Journal of Plant Pathology 76: 196-204. - doi: 10.1007/ BF01974331

Mittempergher L, La Porta N (1991). Hybridization studies in the Eurasian species of elm ( $\mathrm{Ul}$ mus ssp.). Silvae Genetica 40: 237-243.

Mittempergher L, Santini A (2004). The history of elm breeding. Investigación agraria: Sistemas y Recursos Forestales 13: 161-177.

Murray MB, Cannell MGR, Smith RI (1989). Date of budburst of fifteen tree species in Britain following climatic warming. Journal of Applied Ecology 26: 693-700. - doi: 10.2307/2404093

Murray MB, Smith RI, Leith ID, Fowler D, Lee HSJ, Friend AD, Jarvis PG (1994). Effect of elevated $\mathrm{CO}_{2}$ nutrition and climatic warming on bud phenology in Sitka spruce (Picea sitchensis) and their impact on the risk of frost damage. Tree Physiology 14: 691-706. [online] URL: http://treephys.oxfordjournals.org/cgi/content/abstract/14/7-8-9/691

Myking T, Heide OM (1995). Dormancy release and chilling requirement of buds of latitudinal ecotypes of Betula pendula and B. pubescens. Tree Physiology 15: 697-704. [online] URL: http://treephys.oxfordjournals.org/cgi/content/abstract/15/11/697

Myking T, Skrøppa T (2007). Variation in phenology and height increment of northern Ulmus glabra populations: implications for conservation. Scandinavian Journal of Forest Research 22: 369-374. - doi: 10.1080/02827580701672121 Neely D (1968). Twig inoculations on American elm with Ceratocystis ulmi. Phytopathology 58: 1566-1570.

Neely D (1970). Dutch elm disease symptom progression. Plant Disease Report 54: 127-129.

Newbanks D, Bosh A, Zimmermann MH (1983). Evidence for xylem disfunction by embolization in Dutch elm disease. Phytopatology 73: 10601063. - doi: 10.1094/Phyto-73-1060

Ouellette GB, Rioux D (1992). Anatomical and physiological aspects of resistance to Dutch elm disease. In: "Defense mechanisms in woody plants against Fungi" (Blanchette A, Biggs R eds). Springer-Verlag, Berlin, pp. 257-305.

Ouellette GB, Rioux D, Simard M, Cherif M (2004a). Ultrastructural and cytochemical studies of host and pathogens in some fungal wilt diseases: retro- and introspection towards a better understanding. Investigación agraria: Sistemas y Recursos Forestales 13 (1): 119-145.

Ouellette GB, Rioux D, Simard M, Chamberland H, Cherif M, Baayen RP (2004b). Ultrastructure of the alveolar network and its relation to coating on vessel walls in elms infected by Ophiostoma novo-ulmi and in other plants affected with similar wilt diseases. Investigación agraria: Sistemas y Recursos Forestales 13 (1): 147-160.

Pajares JA (2004). Elm breeding for resistance against bark beetles. Investigación agraria: Sistemas y Recursos Forestales 13 (1): 207-215.

Pinon G, Husson C, Collin E (2005). Susceptibility of native French elm clones to Ophiostoma novo-ulmi. Annals of Forest Science 62: 689696. - doi: 10.1051/forest:2005066

Pomerleau R (1965). The period of susceptibility of Ulmus americana to Ceratocystis ulmi under conditions prevailing in Quebec. Canadian Journal of Botany 43: 787-792. - doi: 10.1139/ b65-089

Pomerleau R (1968). Progression et localisation de l'infection par le Ceratocystis ulmi dans l'orme d'Ameérique. Phytopathologische Zeitschrift 63: 301-327. - doi: 10.1111/j.1439-0434.1968. tb02396.x

Pope SA (1943). Some studies on the Dutch elm disease and the causal organism. Doctoral Thesis, Cornell University, Ithaca (NY), USA.

Richards WC (1993). Cerato-ulmin: a unique wilt toxin of instrumental importance in the development of Dutch elm disease In: "Dutch elm disease research: cellular and molecular approaches" (Sticklen M, J. Sherald J eds). Springer Verlag, New York, USA, pp. 89-151.

Rioux D (1996). Compartmentalization in trees: new findings during the study of Dutch elm disease. In: "Histology, ultrastructure and molecular cytology of plant-microorganism interactions" (Nicole M, Gianinazzi-Pearson V eds). Kluwer Academic, Dordrecht, The Netherlands, pp. 211-225.

Rioux D, Ouellette GB (1989). Light microscope observations of histological changes induced by Ophiostoma ulmi in various non-host trees and shrubs. Canadian Journal of Botany 67: 2335 2351. - doi: 10.1139/b89-299

Rioux D, Ouellette GB (1991a). Barrier zone formation in host and nonhost trees inoculated with Ophiostoma ulmi. I. Anatomy and histochemistry. Canadian Journal of Botany 69: 20552073. - doi: 10.1139/b91-258

Rioux D, Ouellette GB (1991b). Barrier zone formation in host and nonhost trees inoculated with Ophiostoma ulmi. II. Ultrastructure. Canadian Journal of Botany 69: 2074-2083. - doi: 10.1139/b91-259

Rioux D, Nicole M, Simard M, Ouellette GB 
(1998). Immunocytochemical evidence that secretion of pectin occurs during gel (gum) and tylosis formation in trees. Phytopathology 88(6): 494-505. - doi: 10.1094/PHYTO.1998.88.6.494

Rohring E (1996). Elms in Europe: ecology and Dutch elm disease. Forstarchiv 67: 179-198.

Rudinsky JA (1962). Ecology of Scolytidae. Annual Review of Entomology 7: 327-348. - doi: 10.1146/annurev.en.07.010162.001551

Sacchetti P, Tiberi R, Mittempergher L (1990). Preference of Scolytus multistriatus (Marsham) during the gonad maturation phase between two species of elm. Redia 73: 347-354.

Santamour FS (1979). Resistance of Himalayan small-leaved elm to Dutch elm disease. Journal of Arboriculture 5: 110-112.

Santini A, Ghelardini L, Falusi M, Bohnens J, Buron M, Collin E, Solla A, Van den Broeck A (2004). Vegetative bud-burst variability of European elms. In: "New approaches to elm conservation". Proceedings of the $2^{\text {nd }}$ International Elm Conference, Valsaìn (Spain) 20-23 May 2003. Investigatión Agraria: Sistemas y Recursos Forestales 13 (1): 37-45.

Santini A, Fagnani A, Ferrini F, Ghelardini L, Mittempergher L (2005). Variation among Italian and French elm clones in their response to Ophiostoma novo-ulmi inoculation. Forest Pathology 35: 183-193. - doi: 10.1111/j.14390329.2005.00401.x

Santini A, La Porta N, Ghelardini, Mittempergher L (2008). Breeding against Dutch elm disease adapted to the Mediterranean climate. Euphytica 163: 45-56. - doi: 10.1007/s10681-007-9573-5

Savolainen O, Pyhajarvi K, Knurr T (2007). Gene flow and local adaptation in trees. Annual Review of Ecology, Evolution and Systematics 38: 595-619. - doi: 10.1146/annurev.ecolsys.38 091206.095646

Sengonca C, Leisse N (1984). Significance of bark beetles (Col. Scolytidae) in the spread of the Dutch Elm Disease in the area of Euskirchen. Journal of Applied Entomology 98 (4): 413-423. Shigo AL (1982). Dutch elm disease: a CODIT perspective In: Proceedings of the "Dutch elm disease symposium and workshop" (Kondo ES, Hiratsuka Y, Denyer WBG eds). Winnipeg (Manitoba - Canada) 5-9 October 1981, pp. 151168.

Shigo AL (1984). Compartmentalization: a conceptual framework for understanding how trees grow and defend themselves. Annual Review of Phytopathology 22: 189-214. - doi: 10.1146/annurev.py.22.090184.001201

Shigo AL, Tippet JT (1981). Compartmentalization of America elm tissues infected with Ceratocystis ulmi. Plant Disease 65: 715-718.
Sinclair WA, Campana RJ (1978). Dutch elm disease, perspectives after 60 years. Cornell University Agricultural Experiment Station, Search (Agriculture) 8: 1-52.

Sinclair WA, Zahand JP, Melching JB (1975). Anatomical markers for resistance of Ulmus americana to Ceratocystis ulmi. Phytopathology 65: 349-352. - doi: 10.1094/Phyto-65-349

Smalley EG (1963). Seasonal fluctuations in susceptibility of young elm seedlings to Dutch elm disease. Phytopathology 53: 846-853.

Smalley EB, Guries RP (1993). Breeding elms for resistance to Dutch elm disease. Annual Review of Phytopathology 31: 325-352. - doi: 10.1146/ annurev.py.31.090193.001545

Smalley EB, Guries RP (2000). Asian elms: source of disease and pest resistance In: "The elms: breeding, conservation, and disease management" (Dunn C ed). Kluver Academic Publishers, Boston, USA, pp. 215-230.

Smalley EB, Kais AG (1966). Seasonal variation in the resistance of various elm species to Dutch elm disease. In: "Breeding pest-resistant trees" (Gerhold HD, Schreiner EJ, Mc Dermott RE, Winieski JA eds). Pergamon Press, Elmsford, NY (USA), pp. 279-292.

Solla A, Gil L (2002). Xylem vessel diameter as a factor in resistance of Ulmus minor to Ophiostoma novo-ulmi. Forest Pathology 32: 123-134. - doi: 10.1046/j.1439-0329.2002.00274. $\mathrm{x}$

Solla A, Bohnens J, Collin E, Diamantis S, Franke A, Gil L, Burón M, Santini A, Mittempergher L, Pinon J, Van den Broek A (2005a). Screening European elms for resistance to Ophiostoma novo-ulmi. Forest Science 51 (2): 134-141.

Solla A, Martin JA, Corral P, Gil L (2005b). Seasonal changes in wood formation of Ulmus pumila and $U$. minor and its relation with Dutch elm disease. New Phytologist 166 (3): 1025-1034. doi: 10.1111/j.1469-8137.2005.01384.x

Sticklen MB, Bolyard MG, Hajela RK, Duchesne LC (1991). Molecular and cellular aspects of Dutch elm disease. Phytoprotection 72: 1-13.

Stipes RJ, Campana R (1981). Compendium of elm diseases. American Phytopathological Society, St. Paul, MN (USA), pp. 66.

Sutherland ML, Pearson S, Brasier CM (1997). The influence of temperature and light on defoliation levels of elm by Dutch elm disease. Epidemiology 87 (6): 576-581.

Takai S, Kondo ES (1979). Seasonal development of Dutch elm disease on white elms in Central Ontario, Canada. I. Following wound inoculation. Canadian Journal of Botany 57: 341-352. doi: 10.1139/b79-046

Tchernoff V (1965). Methods for screening and for the rapid selection of elms for resistance to Dutch elm disease. Acta Botanica Netherlandica 14: 409-452.

Temple B, Horgen PA (2000). Biological roles for cerato-ulmin, a hydrophobin secreted by the elm pathogens, Ophiostoma ulmi and O. novo-ulmi. Mycologia 92 (1): 1-9. - doi: 10.2307/3761443

Townsend AM (1971). Relative resistance of diploid Ulmus species to Ceratocystis ulmi. Plant Disease Reporter 55: 980-982.

Ware G (1995). Little-known elms from China: landscape tree possibilities. Journal of Arboriculture 21: 284-288.

Webber JF (2000). Insect vector behaviour and the evolution of Dutch elm disease. In: "The elms: breeding, conservation and disease management" (Dunn CP ed). Kluwer Academic Publishers, Boston, USA, pp. 47-60.

Webber JF (2004). Experimental studies on factors influencing the transmission of Dutch elm disease. Investigación agraria: Sistemas y Recursos Forestales 13 (1): 197-205.

Webber JF, Brasier CM (1984). The transmission of Dutch elm disease: a study of the process involved. In: "Invertebrate-microbial interactions" (Anderson JM, Rayner ADM, Walton D eds). Cambridge University Press, Cambridge, UK, pp. 271-306.

Whiteley RE, Black-Samuelsson S, Jansson G (2003). Within and between populations variation in adaptive traits in Ulmus laevis Pall., the European white elm. Forest Genetics 10 (4): 313 323.

Worrall J, Mergen F (1967). Environmental and genetic control of dormancy in Picea abies. Physiologia Plantarum 20: 733-745. - doi: 10.1111/j.1399-3054.1967.tb07217.x

Zimmermann MH, McDonough J (1978). Dysfunction in the flow of food. In: "Plant disease an advanced treatise. Vol III. How plants suffer from disease" (Horsfall JG, Cowling ED eds). Academic Press, New York, USA, pp. 117-140.

Zalapa JE, Brunet J, Guries RP (2007). Hybridization and introgression patterns between native red elm (Ulmus rubra Muhl.) and exotic, invasive Siberian elm (Ulmus pumila L.) examined using species-specific microsatellite markers. In: Proceedings of "CONGEN3: The Third International Conservation Genetics Symposium", New York (USA) 27-29 September 2007, pp. 20.

Zalapa JE, Brunet J, Guries RP (2009). Patterns of hybridisation and introgression between invasive Ulmus pumila (Ulmaceae) and native U. rubra. American Journal of Botany 96: 116-1128. - doi: 10.3732/ajb.0800334 